\title{
Detection of Ramularia collo-cygni DMI- and SDHI-resistant field populations in Austria and the effect of fungicides on the population and genetic diversity
}

\author{
Thomas Assinger $\cdot$ James Fountaine $\cdot$ Stefano Torriani $\cdot$ Salvatore Accardo \\ Regula Bernhard-Frey $\cdot$ John Gottula $\cdot$ Siegrid Steinkellner
}

Accepted: 15 November 2021 / Published online: 25 November 2021

(C) The Author(s) 2021

\begin{abstract}
Winter barley (Hordeum vulgare L.) is the third most cultivated crop after corn and wheat in Austria but one of the most challenging for disease control. The foliar pathogen Ramularia collocygni B. Sutton and J.M. Waller, causing Ramularia leaf spots (RLS), is one of the most important diseases in barley. In the recent years, control has only been achieved using fungicide mixtures including the multi-site inhibitor chlorothalonil, however this
\end{abstract}

Supplementary Information The online version contains supplementary material available at https://doi. org/10.1007/s10658-021-02422-5.

T. Assinger

Syngenta Agro GmbH, Anton-Baumgartner-Straße

125/2/3/1, 1230 Wien, Austria

J. Fountaine

Jealott'S Hill International Research Centre,

Bracknell RG42 6EY, UK

S. Torriani $\cdot$ S. Accardo $\cdot$ R. Bernhard-Frey

Syngenta Crop Protection AG, 4332 Schaffhauserstrasse,

Stein, Switzerland

J. Gottula

SAS Institute, 100 SAS Campus Drive, Cary, NC 27513, USA

\section{S. Steinkellner $(\bowtie)$}

Department of Crop Sciences, Institute of Plant Protection, University of Natural Resources and Life Sciences,

Vienna, Konrad-Lorenz-Strasse 24, 3430 Tulln, Austria

e-mail: siegrid.steinkellner@boku.ac.at compound is totally banned in the EU. The objective of this study was to assess fungicide dose-rates and spray mixtures for RLS control. Furthermore, a field monitoring within the main barley growing areas of Austria was carried out, to analyse the current resistance situation to DMI and SDHI fungicides, which are still the backbone in RLS control. The results indicate that only the mixture with chlorothalonil achieved a good RLS control. Prothioconazole or benzovindiflupyr (alone or additively) decrease the severity of RLS but increase the local frequency of Cyp51 and $s d h C$ mutations, especially the high dose rates. Based on a low Cyp51 mutation frequency of $16 \%$ in untreated control this frequency increased over 3.8 times following an application with $300 \mathrm{~g} \mathrm{ha}^{-1}$ prothioconazole. The cumulative-sdhC mutations were even more increased after an application with benzovindiflupyr. This study showed that Ramularia collocygni is present in $91 \%$ of barley fields presented in this field survey. Widespread use of chlorothalonil fungicide maintained a low to moderate mutation frequency (Cyp51-I325T, Cyp51-I328L，sdhC-H146R and $s d h C$-H153R) in Austrian barley regions with no increase between 2017 and 2019.

Keywords Ramularia collo-cygni $\cdot$ Fungicide resistance $\cdot$ Demethylation inhibitors $\cdot$ Succinate dehydrogenase inhibitors 


\section{Introduction}

Over the last years, Ramularia leaf spot (RLS) disease has become one of the most important threats in barley (Hordeum vulgare L.). The causal agent of this late season disease is Ramularia collo-cygni B. Sutton and J.M. Waller which is an important pathogen of barley across many climates (Havis et al., 2015; McGrann \& Havis, 2017) and has been detected in barley samples worldwide (Stam et al., 2019). The fungal pathogen causes necrotic leaf spots with the awns and grains also affected. The disease rapidly increases after flowering, the infection is also accompanied by premature senescence, loss of green leaf area (GLA) and substantial yield losses of around 25\% (Harvey, 2002). In addition, barley is also susceptible to other foliar diseases such as powdery mildew of barley (Blumeria graminis f. sp. hordei), net blotch (Pyrenophora teres), barley scald (Rhynchosporium secalis) and leaf rust of barley (Puccinia hordei). The main management strategies against these fungal diseases are focused on crop rotations, resistant or tolerant varieties in combination with fungicide treatments (Hess et al., 2009). In the recent years, numerous successes have been realized in breeding new varieties which are resistant to some of these diseases: e.g. mildew resistance locus 0 (MLO) genes are used in breeding new varieties for powdery mildew resistance but these genes have no effect on R. collo-cygni in grain (Hofer et al., 2015). Another study by McGrann et al. (2020) concluded that the Enhanced Magnaporthe Resistance locus (EMRl) reduce RLS development. Additionally, only a few data of quantity of sporulation between different varieties (Hoheneder et al., 2021) or different culture parameters like light or nutrients (Sghyer \& Hess, 2019) are available. Furthermore, there are already existing differences between varieties in RLS development (Hoheneder et al., 2021; Mulhare et al., 2021). However, appropriate barley varieties fully resistant to $R$. collo-cygni are not yet available for a grower (Havis et al., 2015; Hein, 2019). Thus, fungicide treatments are still an essential tool to ensure a healthy, high-yielding, and high-quality barley crop.

In the European market, fungicides are subject to continuous change and will be strongly limited in the future. Chlorothalonil-a multi-site inhibitor which is a very effective chemical in control of RLS (Havis et al., 2020)—had the latest EU date of use May 20, 2020 (AGES 2020). Therefore, new fungicide strategies for RLS control will be required, especially in the light of fungicide resistance. Resistance to fungicides will be favoured especially when fungicides with a single site of action are applied (Brent \& Hollomon, 2007). This is also reflected in $R$. collo-cygni, which showed fast adaptability to quinone-outside inhibitors (QoIs), demethylation inhibitors (DMIs) and succinate dehydrogenase inhibitors (SDHIs), the main group of fungicides used in barley crops (Rehfus et al., 2019). Fungicides based on QoIs (strobilurins, e.g. azoxystrobin) were first launched in 1996 and provided initially good control of RLS, however resistance quickly developed. A point mutation at codon $143, \mathrm{G} 143 \mathrm{~A}$ in the cytochrome $b$ gene in $R$. collocygni gives full resistance to QoI fungicides (Leadbeater, 2012). In another study, 93\% of tested isolates were highly resistant to strobilurins in 2015 (Matsuzaki et al., 2019). This underlines the fact that a quick development of strobilurin resistance resulting in a full resistance in $R$. collo-cygni within 2 years had taken place (Fountaine \& Fraaije, 2009).

The triazolinthione derivate prothioconazole is a systemic fungicide and belongs to the group of demethylation inhibitors (DMIs). The widely used curative and protective fungicide inhibits the $14 \alpha$-sterol demethylation enzyme (CYP51) and leads to an inhibition of fungal growth (Parker et al., 2011; Stammler \& Semar, 2011). Compared to other single-site inhibitors such as QoIs or SDHIs, resistance development to DMIs is not so fast and substances within the group are slightly different in the development speed and selectivity of resistance (Fraaije et al., 2007). In recent years, reduced sensitivity to the DMIs have already been reported for the wheat pathogen Zymoseptoria tritici (Heick et al., 2017a, 2017b; Leroux \& Walker, 2011). In the study by Rehfus et al. (2019), 12 different amino acid alterations in the coding region of the CYP51 enzyme of $R$. collo-cygni were found. Here, the dominant haplotype was $\mathrm{RccC} 1$, which contains the mutations Cyp51-I381T, Cyp51-I384L and Cyp51-Y459C. After a re-numbering of amino acids, the two mutations Cyp51-I381T and Cyp51-I384L are homolougus to Cyp51-I325T and Cyp51-I328L, which 
occurs always in combination (Torriani S. 2020, personal communication).

The group of succinate dehydrogenase inhibitors (SDHIs) is one of the fastest growing fungicide class, which inhibits the succinate dehydrogenase $(\mathrm{SDH})$ in the mitochondrial respiratory chain. The newer generations of SDHIs, e.g. benzovindiflupyr, have a broad-spectrum of fungal activity, including $R$. collo-cygni (Avenot \& Michailides, 2010; Sierotzki \& Scalliet, 2013). Benzovindiflupyr is a preventive fungicide and due to the reduced stereocentres in the structure when compared to others, e.g. isopyrazam, linked with excellent crop tolerance. An additional physiological effect is a reduced transpiration without negatively affecting photosynthesis. This results in an increase in biomass under water saving conditions (Kuznetsov et al., 2017).

Resistance to SDH fungicides have been reported after a few years of use - first in barley against $P$. teres or $R$. collo-cygni and later in several other pathogens e.g. Z. tritici and Puccinia striiformis in wheat (Cook et al., 2021; Piotrowska et al., 2017a). The SDH enzyme is composed of four nuclear-encoded subunits (sdh-A, sdh-B, sdh-C and sdh-D), whereby subunits sdh-B, sdh-C and sdh-D interact with SDHI fungicides, which can result in amino acid substitutions (GutiérrezAlonso et al., 2017; Sierotzki \& Scalliet, 2013). Most mutations with amino acid substitutions were shown to be in the ubiquinone-binding site sdh-B, with histidine $(\mathrm{H})$ most often replaced with tyrosine (Y) (Sierotzki \& Scalliet, 2013). In the $R$. collo-cygni mutations $s d h C-\mathrm{H} 146 \mathrm{R}$ and $s d h C$-H153R, a histidine at position 146 or 153 were substituted with arginine $(\mathrm{R})$. The mutation $s d h C$-H146R (former notation $s d h C$-H142R) is homologous to mutation $s d h C-\mathrm{H} 134 \mathrm{R}$ of $P$. teres and Alternaria species as well as to the mutation sdhC-H146R of Sclerotinia sclerotiorum. Mutation $s d h C$-H153R (former notation $s d h C$-H149R) is homologous to mutation $s d h C$-H152R and sdhC-H151R of Z. tritici and Venturia inaequalis (Torriani et al., 2017). Both mutations and additionally the amino acid alterations $s d h C-\mathrm{H} 146 \mathrm{~L}$, $C$-G91R and $C$-G171D are associated with a significantly decrease in sensitivity to SDHIs. Furthermore, mutations $s d h C$-N87S, B-T267I and $B-\mathrm{N} 224 \mathrm{~T}$ are linked to a lower resistance factor and not as relevant as the above-mentioned mutations (FRAC 2021). Monitoring programmes in Europe also found mutations $s d h B-264 \mathrm{P}, B-266 \mathrm{R} /$ $\mathrm{Y} / \mathrm{L}, B-\mathrm{I} 268 \mathrm{~V}$, and $C$-R152M which have an impact on SDHI sensitivity (Rehfus et al., 2019).

Due to the economic importance of $R$. collo-cygni and the lack of new active fungicidal compounds against this disease, current fungicides must be used carefully and accordance with strict guidelines to ensure their activity is maintained long as possible. To date, few sound field studies on the effect of different fungicides strategies against RLS in populations with DMI- and SDHI resistant mutations have been conducted and only limited data is available highlighting the current frequencies of Cyp51 and $s d h C$ mutations in populations of $R$. collo-cygni (FRAC 2021; FRAC 2019; Piotrowska et al., 2017a, 2017b; Rehfus et al., 2019; Torriani et al., 2017). In 2016 and 2017 first strains resistant to DMI and SDHI were found in Austria (FRAC 2021; FRAC 2019). The low to moderate DMI and SDHI resistance alleles in Austrian $R$. collo-cygni populations were used as starting point for our investigation. The purpose of this study was (I) to provide an overview about the frequency and distribution of selected Cyp51 and sdhC mutations in R. collo-cygni populations in the main Austrian barley growing areas, (II) to assess the effect of fungicide doses (prothioconazole, benzovindiflupyr and chlorothalonil) on Cyp 51 and $s d h C$ alterations and (III) to evaluate alternative fungicides to enable a replacement strategy without chlorothalonil.

\section{Materials and methods}

Experimental design

Field trials were conducted in the growing season 2017/2018 and 2018/2019, respectively. Both years were considered the warmest in the region since 1961 (ZAMG 2020). The trials were arranged as randomized complete block design with four replicates and a plot size of $15 \mathrm{~m}^{2}$. All fungicides were applied using a plot sprayer in $300 \mathrm{~L} \mathrm{ha}^{-1}$ water at 2.5 bar pressure, with flat fan venturi nozzles (Albutz AVI 80-015), spaced at $25 \mathrm{~cm}$ on the 
sprayer boom. The distance between sprayer boom and the barley plants were kept at $25 \mathrm{~cm}$.

Fungicide dose rate trial

During the growing season 2017/2018, two field trials were carried out in Wels (Upper Austria, Lat 48.20077, Long 14.04151) and St. Poelten (Lower Austria, Lat 48.20618, Long 15.59586). Both trials were located in the main Austrian barley growing areas. The soil type in Wels was a silty loam and the soil type in St. Poelten was a silty clay loam. Local two-row winter barley varieties known for their susceptibility to $R$. collo-cygni were sown in the first week of October 2017 (Wels, cv. SU Vireni; St. Poelten, cv. Sandra). Four commercially available fungicides belonging to three different modes of action and different classes of chemical were used: Proline (prothioconazole; P; Bayer Crop Science, Monheim am Rhein, Germany), Elatus Plus (benzovindiflupyr; B; Syngenta Crop Protection, Basel, Switzerland), Elatus Era (prothioconazole plus benzovindiflupyr; PB; Syngenta Crop Protection, Basel, Switzerland) and Balear (chlorothalonil; FMC Corporation, Philadelphia, USA; tank mixed with Elatus Era; PBC;) (Table 1). At both sites fungicide applications were performed on May 1, 2018 at growth stage (GS) 49 (43-49) and harvest was carried out on June 20, 2018 at Wels and on June 21, 2018 at St. Poelten. From each plot, 15 random leaves of the upper two leaf-layer, were collected at GS 87, dried at room temperature for one day and frozen at $-20{ }^{\circ} \mathrm{C}$ until further use.

\section{Alternative management strategies}

Three field trials were completed in the growing season 2018/2019 to evaluate alternative fungicide management strategies in Kirchdorf am Inn (Upper Austria, Lat 48.296444, Long 13.304712), Marchtrenk (Upper Austria, Lat 48.214329, Long 14.143009) and St. Poelten (Lower Austria, Lat 48.20795, Long 15.59441). For all sites soil type was silt loam. Winter barley (Kirchdorf cv. SU Vireni; Marchtrenk cv. Finola; St. Poelten cv. Anemone) was sown between September 26 and October 1, 2018 and harvest was carried out on July 3, 2019. The fungicide management strategy was developed to protect the barley crop against the main barley diseases. Thus, all plots, except the untreated control, received an early fungicide application at GS 31-32 to protect barley against Oculimacula yallundae, $B$. graminis, $P$. teres, $R$.
Table 1 Fungicide treatments and total amount of active ingredients (a.i.) applied in dose-rate trial

\begin{tabular}{|c|c|c|c|c|}
\hline \multirow[t]{2}{*}{ Treatment*;** } & \multirow[t]{2}{*}{ Product name, dose-rate $\left[1 \mathrm{ha}^{-1}\right]^{* * *}$} & \multicolumn{3}{|c|}{ Active ingredient $\left[\mathrm{g} \mathrm{ha}^{-1}\right]$} \\
\hline & & $\begin{array}{l}\text { Prothio- } \\
\text { conazole }\end{array}$ & $\begin{array}{l}\text { Benzovin- } \\
\text { diflupyr }\end{array}$ & Chlorothalonil \\
\hline UTC & - & & & \\
\hline $\mathrm{P} 25$ & Proline, 0.15 & 38 & & \\
\hline P50 & Proline, 0.30 & 75 & & \\
\hline P100 & Proline, 0.60 & 150 & & \\
\hline P200 & Proline, 1.20 & 300 & & \\
\hline B25 & Elatus Plus, 0.19 & & 19 & \\
\hline B50 & Elatus Plus, 0.38 & & 38 & \\
\hline B100 & Elatus Plus, 0.75 & & 75 & \\
\hline B200 & Elatus Plus, 1.50 & & 150 & \\
\hline PB25 & Elatus Era, 0.25 & 38 & 19 & \\
\hline PB50 & Elatus Era, 0.50 & 75 & 38 & \\
\hline PB100 & Elatus Era, 1.00 & 150 & 75 & \\
\hline PB200 & Elatus Era, 2.00 & 300 & 150 & \\
\hline $\mathrm{PBC} 25$ & Elatus Era, $0.25+$ Balear, 0.25 & 38 & 19 & 180 \\
\hline PBC50 & Elatus Era, $0.50+$ Balear, 0.50 & 75 & 38 & 360 \\
\hline PBC100 & Elatus Era, $1.00+$ Balear, 1.00 & 150 & 75 & 720 \\
\hline PBC200 & Elatus Era, $2.00+$ Balear, 2.00 & 300 & 150 & 1440 \\
\hline
\end{tabular}


secalis and P. hordei between April 9 and April 11, 2019. The main application against RLS was performed at GS 39-49 (Kirchdorf May 6; Marchtrenk May 7; St. Poelten May 2) and GS 49-59 (Kirchdorf and Marchtrenk May 16; St. Poelten May 17) according to Table 2.
Disease scoring, green leaf area and yield assessment

Disease was assessed using EPPO protocol (Anon. 2012). Visual disease assessments for $R$. collo-cygni were carried out at four random positions per plot. The percentage diseased leaf area (disease severity,

Table 2 Fungicide treatments, application timings, dose rates and the total amount of active ingredients (a.i.) applied in trials with alternative management strategies

\begin{tabular}{|c|c|c|c|c|c|c|c|c|c|}
\hline Treatment & GS $31-32$ & Dose & & GS 39-49 & Dose & & GS 49-59 & Dose & \\
\hline & & $\mathrm{L} / \mathrm{kg} \mathrm{ha}^{-1}$ & a.i. (g) & & $\mathrm{L} / \mathrm{kg} \mathrm{ha}^{-1}$ & a.i. (g) & & $\mathrm{L} / \mathrm{kg} \mathrm{ha}^{-1}$ & a.i. $(\mathrm{g})$ \\
\hline 1 & UTC* & & & & & & & & \\
\hline 2 & $\begin{array}{l}\text { Cyprod- } \\
\text { inil+Met- } \\
\text { conazole }\end{array}$ & $0.5+1.0$ & $375 / 60$ & $\begin{array}{c}\text { Prothiocona- } \\
\text { zole/Benzo- } \\
\text { vindiflupyr }\end{array}$ & 1.0 & $150 / 75$ & & & \\
\hline 3 & $\begin{array}{l}\text { Cyprod- } \\
\text { inil+Met- } \\
\text { conazole }\end{array}$ & $0.5+1.0$ & $375 / 60$ & $\begin{array}{l}\text { Prothio- } \\
\text { conazole/ } \\
\text { Benzovindif- } \\
\text { lupyr + Chlo- } \\
\text { rothalonil }\end{array}$ & $1.0+1.2$ & $150 / 75 / 600$ & & & \\
\hline 4 & $\begin{array}{l}\text { Cyprod- } \\
\text { inil + Met- } \\
\text { conazole }\end{array}$ & $0.5+1.0$ & $375 / 60$ & $\begin{array}{l}\text { Prothiocona- } \\
\text { zole/Benzo- } \\
\text { vindiflupyr } \\
+ \text { Sulfur }\end{array}$ & $1.0+6.0$ & $150 / 75 / 4800$ & & & \\
\hline 5 & $\begin{array}{l}\text { Cyprod- } \\
\text { inil+Met- } \\
\text { conazole }\end{array}$ & $0.5+1.0$ & $375 / 60$ & $\begin{array}{l}\text { Prothiocona- } \\
\text { zole/Benzo- } \\
\text { vindiflupyr } \\
\text { + Fol- } \\
\text { pet + Adjuvant }\end{array}$ & $1.0+1.5+0.125$ & $150 / 75 / 750 / 80$ & & & \\
\hline 6 & $\begin{array}{l}\text { Cyprod- } \\
\text { inil+ Met- } \\
\text { conazole }\end{array}$ & $0.5+1.0$ & $375 / 60$ & $\begin{array}{l}\text { Prothiocona- } \\
\text { zole/Benzo- } \\
\text { vindiflupyr } \\
\text { + Fol- } \\
\text { pet + Azox- } \\
\text { ystrobin }\end{array}$ & $1.0+1.5+1.5$ & $150 / 75 / 750 / 125$ & & & \\
\hline 7 & $\begin{array}{l}\text { Cyprod- } \\
\text { inil+Met- } \\
\text { conazole }\end{array}$ & $0.5+1.0$ & $375 / 60$ & $\begin{array}{c}\text { Prothiocona- } \\
\text { zole/Benzo- } \\
\text { vindiflupyr }\end{array}$ & 1.0 & $150 / 75$ & Folpet & 1.5 & 750 \\
\hline Active Ing & edients & & & Product name & Company & & & & \\
\hline Cyprodinil & $750 \mathrm{~g} \mathrm{~kg}^{-1}$ & & & Unix ${ }^{\circledR}$ & Syngenta (Switze & land) & & & \\
\hline Metconazo & le $120 \mathrm{~g} \mathrm{~L}^{-1}$ & & & Plexeo $^{\mathrm{TM}}$ & Syngenta (Switze & land) & & & \\
\hline $\begin{array}{c}\text { Prothiocon } \\
\text { lupyr } 75\end{array}$ & azole $150 \mathrm{~g} \mathrm{~L}^{-1}$ & + Benzovir & ndif- & Elatus ${ }^{\mathrm{TM}}$ Era & Syngenta (Switze & land) & & & \\
\hline Chlorothal & nil $500 \mathrm{~g} \mathrm{~L}^{-1}$ & & & Bravo® 500 & Syngenta (Switze & land) & & & \\
\hline Sulfur 800 & $\mathrm{~g} \mathrm{~kg}^{-1}$ & & & Thiovit@ Jet & Syngenta (Switze & land) & & & \\
\hline Folpet 500 & $\mathrm{~g} \mathrm{~L}^{-1}$ & & & $\begin{array}{l}\text { Folpan® } 500 \\
\quad \text { SC }\end{array}$ & Adama (Israel) & & & & \\
\hline $\begin{array}{r}\text { Adjuvant } 6 \\
\text { (= organos } \\
\text { thetic lat }\end{array}$ & $\begin{array}{l}40 \mathrm{~g} \mathrm{~L}^{-1} \\
\text { licone s. fluid } 3 \\
\left.x 255 \mathrm{~g} \mathrm{~L}^{-1}\right)\end{array}$ & $385 \mathrm{~g} \mathrm{~L}^{-1}+$ & syn- & Designer® & Nufarm (Australi & & & & \\
\hline Azoxystrol & in $250 \mathrm{~g} \mathrm{~L}^{-1}$ & & & Amistar ${ }^{\circledR}$ & Syngenta (Switze & land) & & & \\
\hline
\end{tabular}

*UTC $=$ untreated control 
DS \%) on flag leaf (F) and second leaf (F-1) was determined and the fungicide efficacy $(\%)$ was calculated using the formula (Zhang et al., 2020)

$\operatorname{Efficacy}(\%)=\frac{\mathrm{A}(\mathrm{utc})-\mathrm{A}(\mathrm{ft})}{\mathrm{A}(\mathrm{utc})} * 100$

where $A_{(u t c)}=$ mean lesion area in the untreated control (utc) plots and $\mathrm{A}_{(\mathrm{ft})}=$ mean lesion area in the fungicide treated $(\mathrm{ft})$ plots. For the dose-rate trial the area under disease progress curve (AUDPC) (Shaner \& Finney, 1977) between application and GS 87 was calculated from the RLS scores for each plot using the formula

$A U D P C=\sum_{i=1}^{n}\left[\frac{Y_{i+n 1}+Y_{i}}{2}\right] \times\left[X_{i+1}-X_{i}\right]$

where $Y_{i}=$ percent RLS at the ith observation, $\mathrm{X}_{\mathrm{i}}=$ time in days at the ith observation, $\mathrm{n}=$ total number of observations, and $\mathrm{Y}_{0}=\mathrm{X}_{0}=0$. The total number of observations were 3 in St. Poelten and 4 in Wels, respectively.

Green leaf area (GLA) was assessed similarly to disease control and the area under green leaf area curve (AUGLAC) between GS 39 and harvest was calculated using the same formula as for AUDPC whereas $\mathrm{Y}_{\mathrm{i}}=$ percent of GLA at the ith observation. The total numbers of observations were 6 in St. Poelten and 7 in Wels.

Barley was harvested separately for each plot at plant maturity and grain weight were adjusted to $86 \%$ dry matter. Yield was expressed as $\mathrm{dt} \mathrm{ha}^{-1}$.

\section{Field monitoring}

To get an overview about the progress of Cyp51 and $s d h C$ alterations, a field monitoring over the main barley growing areas were carried out in Austria. Therefore, samples from fungicide free barley fields were collected. In 2017, leaves from 7 locations, in 2018 from 29 locations and in 2019 from 22 locations were analysed. 50 leaves with visible RLS per location were randomly collected, dried at room temperature for one day and frozen at $-20{ }^{\circ} \mathrm{C}$ until further use. Leaves of each location were divided into two subsamples and separately analysed. The results are presented as the average frequency from the two subsamples.
Determination of Cyp5I and $s d h C$ alterations associated with fungicide resistance

DNA from punched leaves was extracted and analysed as described by Wullschleger et al. (2015), with adjusted primers and PCR conditions (Torriani S. and Accardo S. 2020; written communication). A singleplex SYBR Green real time PCR assays using 384 well plates were carried out for detection of the quantitative mutations leading to Cyp51-I325T and Cyp51-I328L in the CYP51 enzyme and $s d h C$ H146R and $s d h C-H 153 R$ in the sdh-C gene. The qPCR was established in Syngenta Resistance Centre in Stein, Switzerland. PCR assays were done according to the method described by Assinger et al. (2021).

Data analysis

All linear mixed models were created Proc Mixed procedure of SAS 9.4 (SAS®, SAS Institute Inc., Cary, NC). Degrees of freedom method was kr2 and covariance matrices were CS.

To analyse AUGLAC and resistance frequencies, treatments and sites were considered fixed effects, and the blocks were considered as random effect within the site. Selected data from dose-rate trials were described separately and analysed by location. In field experiments, due to unequal variances, means were compared using Hochberg's GT2 multiple comparison test $(p=0.05)$. A model for mutation presence or absence due to years and loci was created with PROC GENMOD with zero inflated negative binomial distribution. Overdispersion was confirmed and the model fit was adequate (Scaled Pearson $x^{2}>0.05$ ). Map was created with spotfire 10.3 (TIBCO Software Inc., Palo Alto, CA).

To analyse AUDPC and yield, the treatments were parameterized into rate levels by fungicide and log of the standard rates were used to linearize the explanatory variables. There was little evidence of by-site interactions for AUPDC or yield; in the models presented fungicide rates and their interactions were considered fixed and blocks within sites were considered random. The fungicide active ingredients were tested individually and in their full factorial interactions by rate: prothioconazole and benzovindiflupyr were assessed individually and in interaction, and chlorothalonil was assessed only in interaction with prothioconazole and benzovindiflupyr according to the study 
design. The highest degree rate polynomial (quartic) with full factorial was fit. Visual inspection of residual plots verified there were no serious departures from model assumptions. The parameter estimates and confidence intervals are interpreted at the highest polynomial level where Type 1 sum of squares were significant at $p<0.05$.

Additionally, the relationship between fungicide, AUDPC and yield was assessed through causal inference in SAS using Proc Causalmed. Normal mediator (AUDPC) and outcome (yield) distributions were assumed. Each fungicide treatment was considered individually versus the untreated control and covariates used were site, block and rate. Total effects were considered statistically significant for causal interpretation at $p<0.05$.

\section{Results}

In both experimental years 2018 and 2019, RLS achieved between 25 and $93 \%$ infected leaf area on the upper two leaves. Lowest RLS disease severity was assessed with 25\% in Marchtrenk in 2019. Highest values were measured in St. Poelten with $93 \%$ in 2018.

Effect of dose dependent fungicide treatments on disease level, green leaf area, yield and selection pressure on Cyp51- and $s d h C$-mutations

All fungicide treatments significantly increased in green leaf area (except P25 in both sites and B25 in Wels) compared to the untreated control (Figs. 1A \& 2A). The higher dose-rates provided greater increase in AUGLAC in St. Poelten compared to Wels. The strongest effects were obtained, when combining all three active compounds in full (PBC100) or double (PBC200) dosage. These two treatments showed significant differences in AUGLAC and additionally these plots had significant greener leaves compared to other treatments. The higher dose-rates resulted in greener leaves and were associated with a reduced RLS severity.

RLS epidemics were high at both experimental sites. In the untreated control plots RLS severity at GS 87 was $77 \%$ on flag leaf and $87 \%$ on second leaf in Wels and $91 \%$ on flag leaf and 95\% on second leaf in St. Poelten, respectively an AUDPC level of 1119 for Wels and 1232 for St. Poelten. All fungicide treatments reduced AUDPC compared to the untreated control, and progressive disease reductions corresponded to dose rate (Fig. 3, Supplementary Table S1). Linear and quadratic terms for prothioconazole and benzovindiflupyr were significant, as was their first order interaction. Additionally, benzovindiflupyr had a significant interaction with prothioconazole on a quadratic basis, which accounts for means separation at the highest rates tested (Fig. 3, Supplementary Table S1). The disease control effect of the two fungicides combined together was partially additive.

We evaluated chlorothalonil as an "add-on" to prothioconazole and benzovindiflupyr. Treatments including chlorothalonil reduced disease significantly across rates of prothioconazole plus benzovindiflupyr. The interaction between chlorothalonil and prothioconazole and benzovindiflupyr was statistically significant up to the quadratic term: The effect of these three fungicides were more pronounced at the higher treatment levels (Fig. 3). Treatments at the 100\% and $200 \%$ rate levels (PBC100 \& PBC200) had very low or zero disease, respectively.

The mean yield in the untreated control was 67 $\mathrm{dt} \mathrm{ha}^{-1}$. There was a statistically significant linear effect of fungicides to yield (Fig. 4, Supplementary Table S2). Fungicide treatments were generally additive for yield. There were no interactions between prothioconazole and benzovindiflupyr, but there was a significant linear interaction between chlorothalonil and benzovindiflupyr, illustrating the marginally less efficacy of benzovindiflupyr than combined fungicide treatments at higher rates (Fig. 4, Supplementary Table S2).

The prothioconazole and prothioconazole plus benzovindiflupyr treatment showed a statistically significant causal effect. Total yield increases across rates were 4.5 and $4.8 \mathrm{dt} \mathrm{ha}^{-1}$ respectively. The percent yield increase mediated by AUDPC reduction was $85 \%(p<0.05)$ for prothioconazole plus benzovindiflupyr treatment. The correlation between yield and AUDPC (Supplementary Fig. S1) shows that prothioconazole has a steeper yield reduction through higher AUDPC than benzovindiflupyr.

The fungicide treatments resulted in different mutation patterns in $R$. collo-cygni populations at both experimental sites (Figs. 1B,C \& 2B,C). Due to the clear positive correlation between Cyp51-I325T 


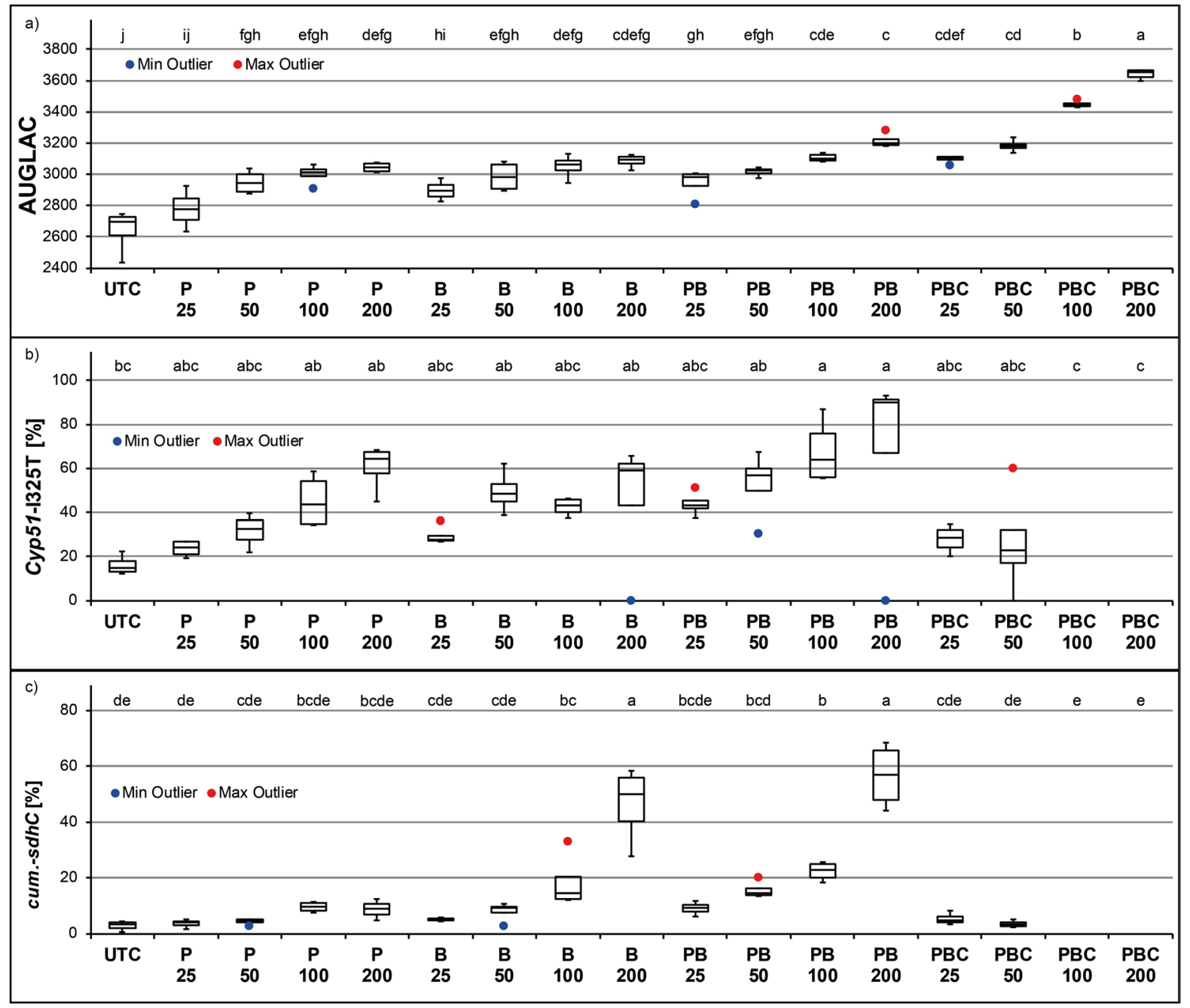

Fig. 1 Box plots of a) area under green leaf area curve (AUGLAC), b) frequency of Cyp51 mutation (carrying the I325T allele) and c) frequency of cum.-sdhC mutation (cumulative sdhC-H146R and -H153R) in Ramularia collo-cygni

and Cyp51-I328L $\left(\mathrm{R}^{2}=0.97\right)$ only data from Cyp51I325T were shown. In Wels, the population in the untreated control plots reached 3.3 times higher Cyp51-I325T frequencies compared to St. Poelten (53.8\% and $16.1 \%$; Fig. 1B \& 2B). Frequencies in Cyp51-I325T mutations were more pronounced in the prothioconazole and prothioconazole plus benzovindiflupyr treatments compared to the benzovindiflupyr treatment. In St. Poelten (Fig. 1B), a doseresponded increase of Cyp51-I325T was shown by applying $\mathrm{P}$ and $\mathrm{PB}$. Compared to the untreated control, treatment PB100 and PB200 significantly populations as a result of different fungicide treatments in St. Poelten (4 plots/treatment). Different letters above the box plots indicate significant differences according to GT2-Hochberg test $(p=0.05)$

increased Cyp51-I325T frequencies from 16 to $68 \%$. Chlorothalonil in the treatments PBC100 and PBC200 showed a good performance against RLS and with the used method no resistant strains could be detected. The result for the mutation Cyp51-I325T was similar in Wels (Fig. 2B), whereby especially the PB treatments showed no increase of mutation during increased dose rates. Chlorothalonil treatments (PBC) slightly increased the Cyp51-I325T frequencies to $\pm 70 \%$ by applying PBC25, PBC50 and $\mathrm{PBC} 100$ and significantly decreased to zero in treatment PBC200. 


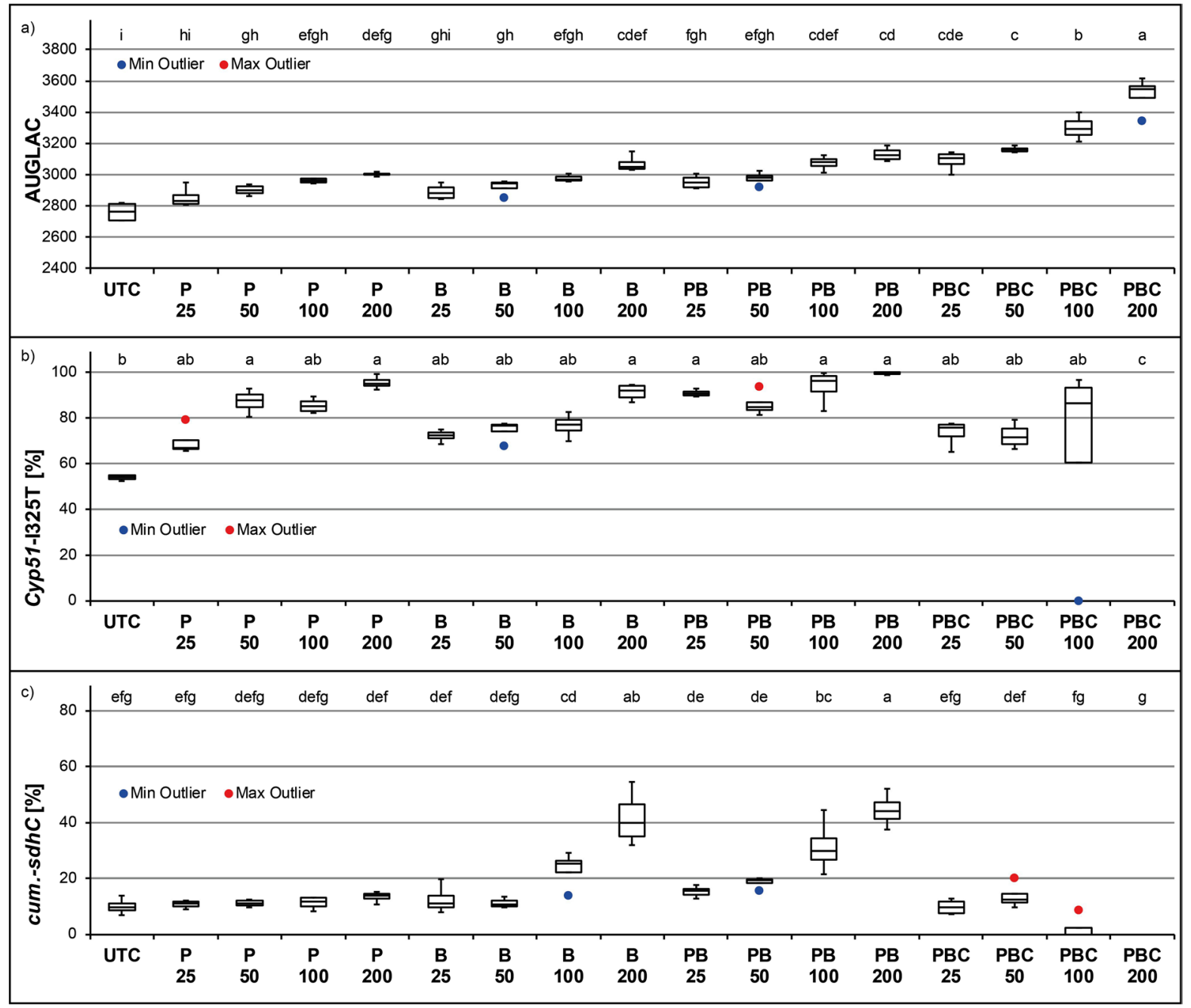

Fig. 2 Box plots of a) area under green leaf area curve (AUGLAC), b) frequency of Cyp51 mutation (carrying the I325T allele) and c) frequency of cum.-sdhC mutation (cumulative sdhC-H146R and -H153R) in Ramularia collo-cygni

The point mutations $s d h C$-H146R and $s d h C$ H153R were measured on a low level and in different frequencies. To include both mutations in one value, the cumulative frequency (cum.) of $s d h C$-H146R and $s d h C$-H153R mutations was calculated and represented as cum.-sdhC. In Wels, cum.-sdhC in untreated control reached higher frequencies compared to St. Poelten (Figs. 1C \& 2C), in detail cum.-sdhC in Wels (10.1\%) was 3.6 times higher compared to St. Poelten (2.8\%). Compared to the untreated control, changes in frequency of cum.-sdhC were more or less stable through prothioconazole and heavily increased populations as a result of different fungicide treatments in Wels (4 plots/treatment). Different letters above the box plots indicate significant differences according to GT2-Hochberg test $(\mathrm{p}=0.05)$

through high SDHI dosage of benzovindiflupyr (B) or prothioconazole plus benzovindiflupyr (PB). In both locations, treatments B100, B200, PB100 and PB200 significantly increased the cum.-sdhC frequencies compared to untreated control. Additionally, significant differences were found between B100 and B200 as well as between PB100 and PB200. In St. Poelten (Fig. 1C), fungicide application with $75 \mathrm{~g}$ benzovindiflupyr (B100) or additionally with $150 \mathrm{~g}$ prothioconazole (PB100) increased the cum.-sdhC frequencies more than sixfold (from $2.8 \%$ to over $18 \%$ ). At twice the amount (treatment B200 and PB200), cum.-sdhC 
Fig. 3 Fitted quadratic curves for RLS AUDPC level treated with various doses, up to twice the recommended rate $0.5=50 \%, 1=100 \%$ and $2=200 \%$ of recommended rate; according Table 1; based on Log 10 transformation for fungicide rates), of prothioconazole (P), benzovindiflupyr (B), prothioconazole + benprothioconazole + benzovindiflupyr + chlorothalonil (PBC). Bands show the 95\% confidence limits $(\mathrm{Cl})$ per hectare $(0.25=25 \%$, zovindiflupyr (PB) and

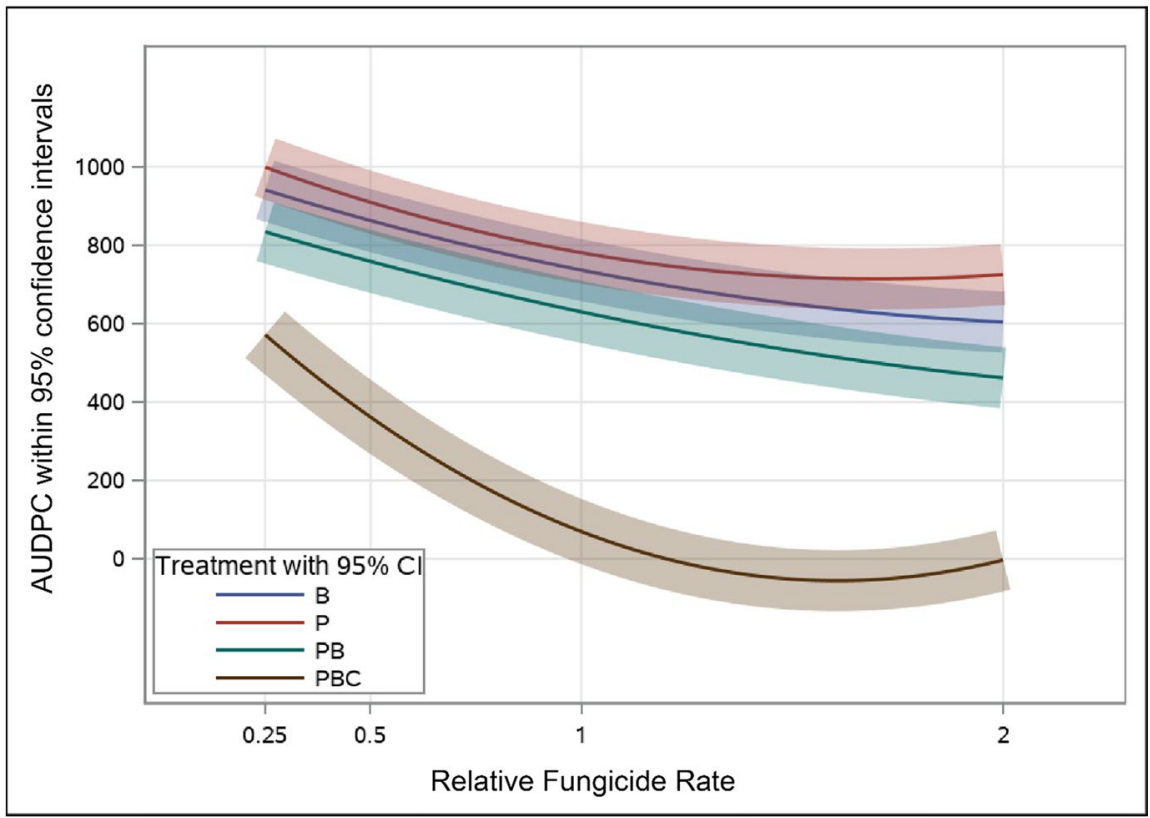

Fig. 4 Fitted linear curves for yield $\left(\mathrm{dt} \mathrm{ha}^{-1}\right)$ treated with various doses, up to twice the recommended rate per hectare $(0.25=25 \%$, $0.5=50 \%, 1=100 \%$ and $2=200 \%$ of recommended rate; according Table 1; based on Log 10 transformation for fungicide rates), of prothioconazole (P), benzovindiflupyr (B), prothioconazole + benzovindiflupyr (PB) and prothioconazole + benzovindiflupyr + chlorothalonil (PBC). Bands show the 95\% confidence limits $(\mathrm{Cl})$

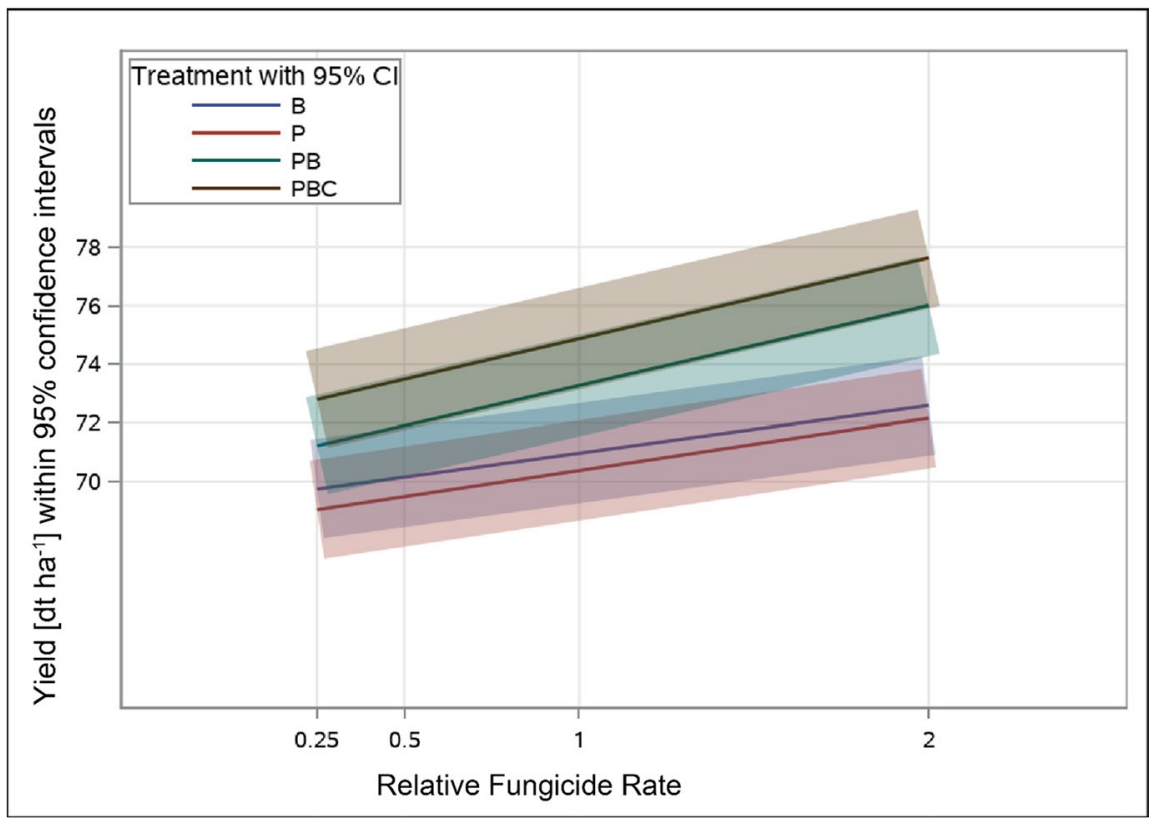

increased between 17 and 20 times (46.4-56.6\%). In Wels, under a higher cum.-sdhC population in the untreated control, the increase was not that high compared to St. Poelten. Here, the frequencies increased 2 to 3 times after application B100 and PB100 and 4 times after application B200 and PB200, respectively (Fig. 2C). Within the chlorothalonil treatments, the low dose-rates in treatment $\mathrm{PBC} 25$ and PBC50 resulted in a stable cum.-sdhC and treatment PBC100 or PBC200 decreased cum.-sdhC, with no significant differences compare to untreated control. 
Frequency and distribution of Cyp51-and $s d h C$-resistant R. collo-cygni population in Austria—a field monitoring

An intensive monitoring program over the main Austrian barley growing areas was started in 2017 to get an overview about the frequency of the most important Cyp51 and sdhC mutations. Resistance mutations leading to the amino acid alteration Cyp51-I325T, Cyp51-I328L, sdhC-H146R and $s d h C$-H153R have been identified with pyrosequencing and are shown in Fig. 5 and Supplementary Table S3. In total, 58 barley fields were analysed between 2017 and 2019 from different Austrian sites. In 2018, no Ramularia collo-cygni DNA was detected in samples from the Mannersdorf and Leobersdorf sites, and in 2019 from Grafenschlag, Harmannsdorf I and Mannersdorf. Leaves collected in Grafenschlag and Harmannsdorf I showed clear symptoms of $P$. teres not RLS. After microscopic examination of leaves from Mannersdorf and Leobersdorf also no typical RLS symptoms were found.
Frequencies of mutations varied among loci $(p<0.0001)$. The frequencies for each mutation were significantly different from each other, expect for Cyp51-I325T versus Cyp51-I328L. Estimated Cyp51-I325T frequencies were $18.8 \%$ and was not significantly different from Cyp51-I328L (19.7\%). The estimated frequency of $s d h C$-H146R was $2.0 \%$. The alteration $s d h C-\mathrm{H} 153 \mathrm{R}$ was found in lowest frequencies within an estimate of $1.1 \%$. Estimates of mutation frequencies declined year on year; the year effect was noteworthy though not statistically significant $(p=0.0571)$ at this level of replication (5-27 samples per locus year). 2019 showed a lower frequency with an odds ratio of mutation of 0.65 versus other years. The decline of the frequency of each mutation indicates there is no increase and very likely, a decrease of fungicide resistance loci in the populations surveyed (Fig. 6).

Due to the good correlation within Cyp51 mutations $\left(\mathrm{R}^{2}=0.933\right.$; field monitoring data; data not shown) only data from Cyp51-I325T and cum.-sdhC

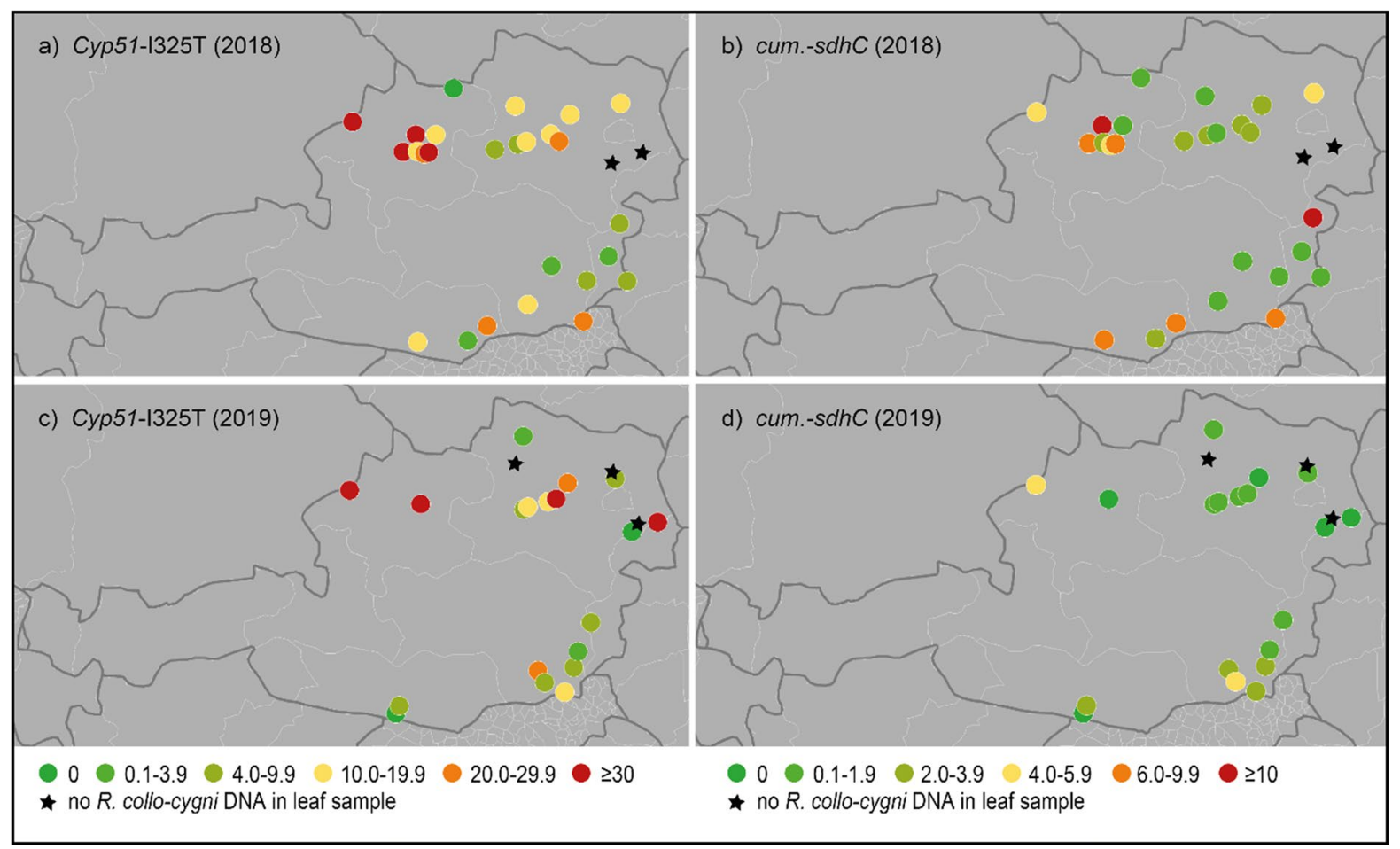

Fig. 5 Distribution and frequency (\%) of a) cyp51-I325T in 2018, c) in 2019 and b) cum.-sdhC mutation in 2018 and d) 2019 in Austrian leaf samples 
Fig. 6 Model fit estimated frequencies of tested mutations (sdhC-H146R, sdhCH153R, Cyp51-I 325 T and Cyp51-I391L) over the years. The error bars show the $95 \%$ confidence limits (Cl)

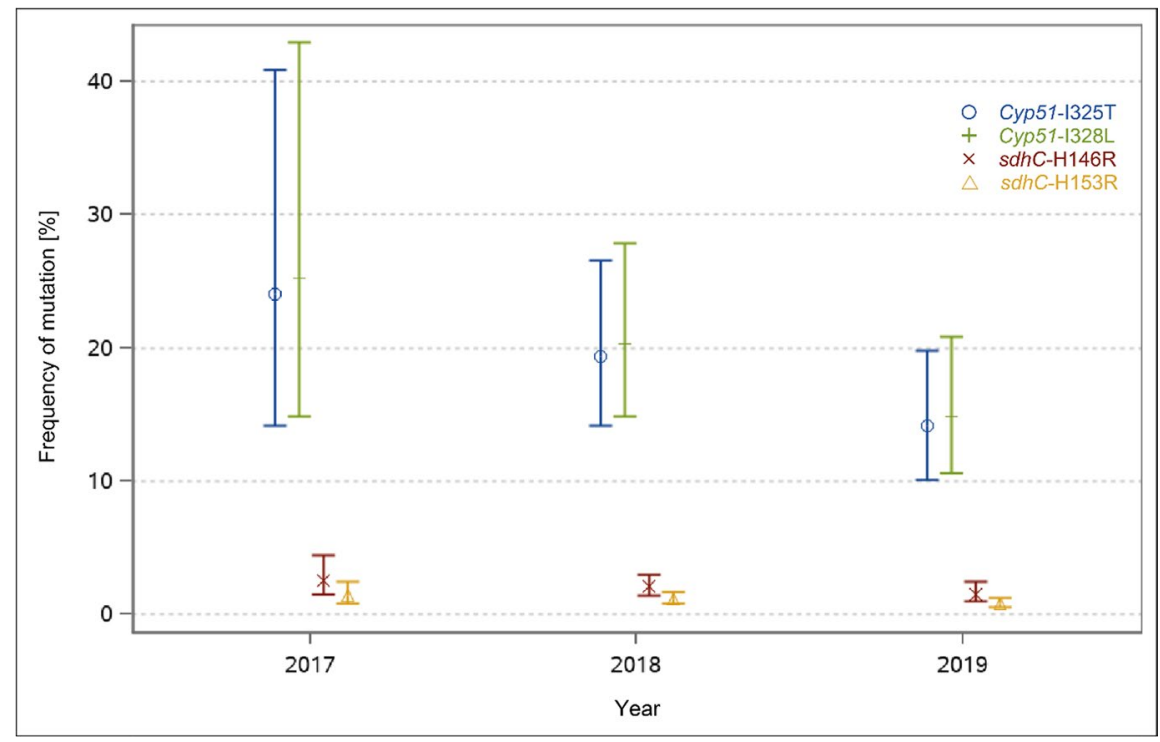

were shown (Fig. 5). At site Goedersdorf (2019), Kleinwilfersdorf (2017) and Wasenbruck (2019) $R$. collo-cygni was detected with qPCR but only wildtype population. In the 3 samples from Gerhaus, Preuwitz and Marchtrenk (2019) no $s d h C$ mutations were found, although these samples showed Cyp51I325T frequencies above 20\%. All other samples, except the 5 samples which did not contain $R$. collocygni DNA, include Cyp51 as well as sdhC mutations. Highest amount of Cyp51-I325T alteration was found in Wels and Rohr/Kremstal (above 47\%) in 2018 and in Gerhaus 49.5\% and Pottenbrunn 72.3\% in 2019. Higher frequencies were more often found in north-west Austria compared to south-east Austria, such as Styria. Nevertheless, in some samples from the south-east, we found also high Cyp51-I325T frequencies: $28 \%$ in St. Poelten (2018), 24\% in St. Paul (2018), and 20\% in Wildon (2019). We also observed differences between years: in the southern Austrian region lower frequencies were found in 2019, in the east (near Vienna) no $R$. collo-cygni was detected in 2018 and in 2019 a sample with 50\% of Cyp51I325T was analyzed. Cum.-sdhC frequencies were generally lower compared to Cyp51-I325T and frequencies were additionally lower in 2019 compared to 2018. Upper Austria showed the most cases with cum.-sdhC frequencies above 6\% in 2018. In 2019 only two locations were tested, whereby one sample showed no mutation and the second sample a low cum.-sdhC mutation of $4.2 \%$. In the east of Austria very low frequencies were found, except of one sample in Drassmarkt (2018). In the south there were 3 locations with more than $6 \%$ cum.-sdhC in 2018 and only one location with more than $4 \%$ in 2019 .

Evaluation of alternative fungicide strategies

In 2019 , three field trials were run to evaluate new fungicide strategies to protect barley against RLS and other diseases. In this year, the RLS epidemics were moderate: In the untreated control (treatment 1) mean Ramularia disease severity on upper two leaves reached 26\% in Marchtrenk, 38\% in Kirchdorf am Inn and $41 \%$ in St. Poelten (Table 3). With chlorothalonil in combination with prothioconazole plus benzovindiflupyr (treatment 3), RLS severity were reduced to under $2.6 \%$, which leads in an efficacy of over $94 \%$. Prothioconazole plus benzovindiflupyr (treatment 2) resulted in an efficacy between 51 and 90\%. Prothioconazole plus benzovindiflupyr showed significantly lower disease severity compared to the untreated control and, in addition, significantly weaker performance than prothioconazole plus benzovindiflupyr plus chlorothalonil in Kirchdorf am Inn and St. Poelten. Adding of sulfur (treatment 4) resulted in a slightly benefit in RLS control compared to prothioconazole plus benzovindiflupyr but was not as good as treatments including folpet. Folpet treatments (treatment 5, 6 and 7) provided an efficacy between 80 and $95 \%$-all three treatments did not differ 


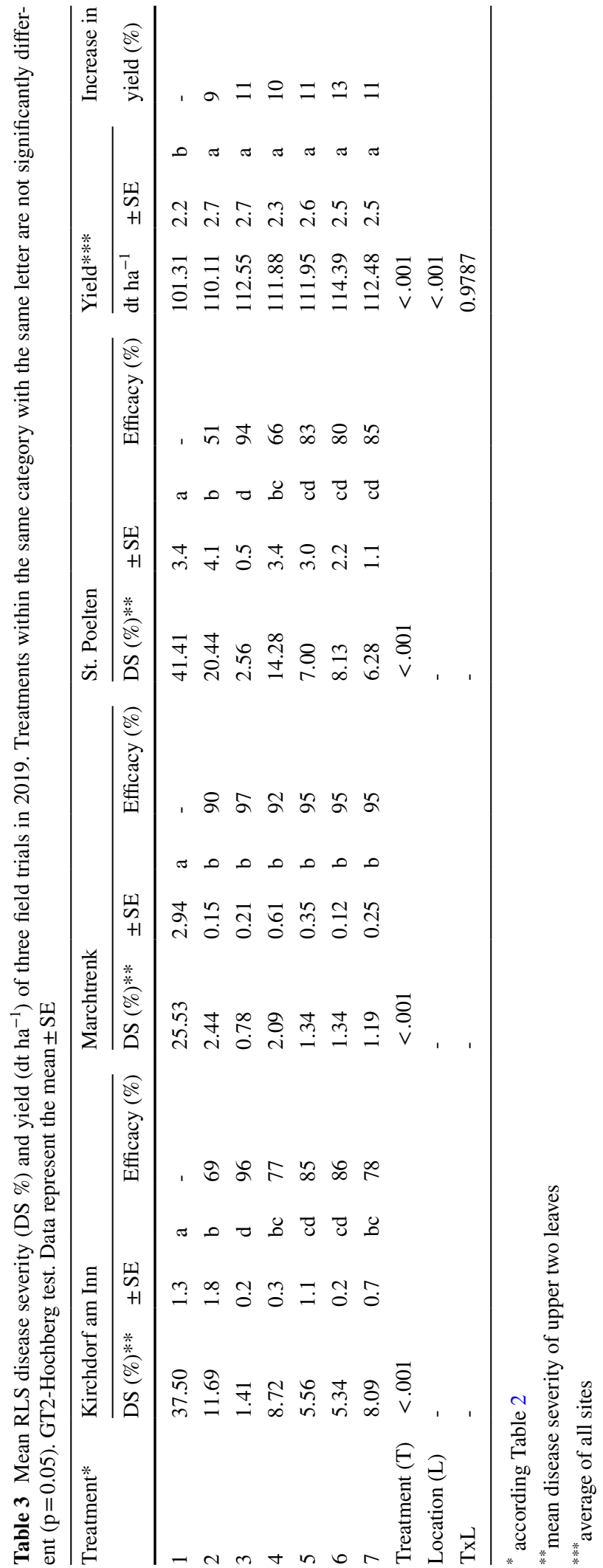


significantly. Average yield of all trials in untreated control was $101.31 \mathrm{dt} \mathrm{ha}^{-1}$. All fungicide treatments significantly increased the yields.

\section{Discussion}

The resistance of fungal pathogens to DMI and SDHI fungicides is an ongoing development. Only by combining all relevant strategies to minimize the population of $R$. collo-cygni it will be possible to slow down the selection process. In our dose-rate experiments four rates of fungicides and three active ingredients in four different strategies have been pursued to explain their impact on disease severity, GLA, yield and the alteration of Cyp51 and $s d h C$ mutations. In 2018, for both sites, a high RLS pressure was observed and resulted in a serious disease severity. Our results indicate that RLS severity was higher for treatments that included a single fungicide (prothioconazole or benzovindiflupyr). AUDPC was reduced by $39 \%$ through prothioconazole and 52\% through benzovindiflupyr, both measured at double the recommended dose rate (P200 and B200). The effects on RLS AUDPC of prothioconazole and benzovindiflupyr were partially additive across rates, and the combination outperformed prothioconazole alone for AUDPC across all rates. There was a tendency for slightly less than expected benzovindiflupyr efficacy at higher rates of prothioconazole. This underlines the principal that two agents with different modes of action should perform additively until dose rate sufficiency is achieved. The mix including chlorothalonil showed much lower AUDPC across rates than that without, including almost no disease at the highest rates. Hence, it was not possible to achieve optimal disease control in this study without the previously most important but now banned active ingredient, chlorothalonil.

Our data from fields with DMI and SDHI resistant $R$. collo-cygni populations, indicate single use of prothioconazole and benzovindiflupyr is not enough to achieve high yields. Additionally, treatments containing multiple chemistries including the multi-site inhibitor chlorothalonil were consistently associated with the highest yields. However, at this level of replication (two sites), the effect of PB was statistically indistinguishable from $\mathrm{PBC}$ for yield, even though the effect of PBC on AUDPC was much higher than PB. Hence, this study suggests that the combination of $\mathrm{P}$ and $\mathrm{B}$ together are necessary to protect yield in the absence of the full disease control conferred by chlorothalonil.

The differences between treatments in the resulting yields were not as pronounced as for disease severity given this level of replication. A recent study also reported that the significant impact of fungicides is not necessarily reflected to the same increase in yield (Stetkiewicz et al., 2019). They pointed out that soil type and soil quality has also a high impact and moreover, that the differences in yield were lower in drier years. Yield is a response to many more factors than disease responses to fungicides. As for many other pathogens, precipitation and temperature are significant factors in yield and disease severity (Wiik \& Ewaldz, 2009). Our experiments were conducted under drier and warmer conditions compared to the long-term average, especially the dry weather conditions before harvest resulted in a rapid ripening and this may have resulted in lower effect of fungicide applications on yield increase. Similarly, a study in wheat and barley in Nordic-Baltic region showed that biotic and abiotic stress like drought affected yield (Jalli et al., 2020). In addition, with other stress factors this could also resulted in decreased yields. Nevertheless, the results of this study showed a causal effect of $\mathrm{P}$ and PB treatments for yield, with $85 \%$ of the yield increases in the PB treated plots attributable to disease suppression. Altogether, this suggests that $\mathrm{PB}$ can protect yields adequately, even in the absence of complete disease control.

The steeper AUDPC reduction at lower prothioconazole or benzovindiflupyr rates in St. Poelten than Wels suggests that there is a higher threshold of these two active ingredients for control at site Wels, where frequencies of resistant population is higher and more developed. This likely reflects that the low to moderate frequencies of Cyp51 and $s d h C$ mutations are the main reasons behind low disease decrease for these fungicide groups. Recurrent treatments with the same fungicide can lead to an increase of resistant mutations in pathogen populations. If then the frequency of mutation becomes a considerable proportion of the population, the efficacy of fungicides can be affected (Torriani et al., 2017). Alternatively, a fungicide strategy which include more active ingredients leads to better disease control, previously reported for pathogens of wheat (Heick et al., 2017a; Lynch et al., 2017; Sylvester \& Kleczewski, 2018; Wieczorek et al., 
2015). Interestingly, chlorothalonil was associated with greater disease reduction at higher Cyp51 and cum.-sdhC frequencies in the untreated control at our Wels experimental site than at St. Poelten, especially at lower prothioconazole and benzovindiflupyr rates. This underlines the power of the multi-site inhibitor in a $R$. collo-cygni population with higher frequencies of tested mutations and supports the importance of rotating modes of action and combining different modes of action to prevent fungicide resistance.

Higher yields were connected to lower RLS disease severity and greener leaves. The AUGLAC is affected by diseases and leaf senescence. The effect of fungicides on leaf senescence is complex and may also be related to the host physiology (Cromey et al., 2004). However, in our study leaf senescence was mainly determined by a short hot period before harvest.

There are several studies on DMI and SDHI resistance of fungal species from field and laboratory mutants of fungi (Avenot \& Michailides, 2010; Cools, 2008; Heick et al., 2017a; Piotrowska et al., 2017a; Rehfus et al., 2019; Torriani et al., 2017; Wieczorek et al., 2015), but there are no previous field studies on the effect of fungicide doserates on the quantitative selection of Cyp51 and $s d h C$ mutations on $R$. collo-cygni populations. In our study, we found that higher dose-rates of prothioconazole lead in higher Cyp51 frequencies and higher dose-rates of benzovindiflupyr lead in higher $s d h C$ frequencies. A selection for fungicides is described for other pathogens and same or other single-site fungicides (Dooley et al., 2016; Heick et al., 2017a; Simoes et al., 2018; Van den Bosch et al., 2011; Zhou \& Mehl, 2020). The review by Van den Bosch et al. (2011) mentioned that field experiments are difficult to determine the effect of fungicide doses on fungicide resistance, except for the selection phase in resistance development. However, they documented that the selection of resistant types mostly increases with higher dose rates. These findings are in line with data of quantitative detection of Cyp51-I325T and cum.-sdhC mutations in this study. Cyp51-I325T frequencies increased with increasing prothioconazole rates and reached a frequency of over $95 \%$ for site Wels. This means that with an application of $300 \mathrm{~g} \mathrm{ha}^{-1}$ prothioconazole (P 200) almost the whole $R$. collo-cygni population is less sensitive to this DMI. Based on a lower
Cyp51-I325T frequency in untreated control in St. Poelten, an application with $300 \mathrm{~g} \mathrm{ha}^{-1}$ prothioconazole (P 200) increased the Cyp51-I325T frequency to over $60 \%$, which means a large increase of 3.8 times. The study by Heick et al. (2017a) reported changes in Cyp51 frequencies after fungicide application in Z. tritici population. They noted a marked increase after three applications of DMI's compared to one application with DMI plus SDHI. Mutations in the sdh-C gene resulted in amino acid changes at codon $146(s d h C$-H146R) and $153(s d h C$-H153R), both represented in cum.-sdhC frequencies. These frequencies were also increased through SDHI application. Comparable for Cyp51-I325T mutation, cum.-sdhC showed a major increase in St. Poelten, where a lower cum.-sdhC frequency in untreated control was present, compared to Wels. The same trend was shown for $s d h C$-I86F in Phakopsora pachyrhizi (Simoes et al., 2018). The authors found in a population with lower $s d h C$-I86F frequencies a major increase after SDHI application and in populations with moderate to high $s d h C$-I86F frequencies no or just a small increase after SDHI application. The benzovindiflupyr treatments (B25-B200) also increased Cyp51-I325T frequencies which is not comparable with the prothioconazole treatments (P25-P200) where no increase in cum.-sdhC frequencies were found. However, there is a lack in field research on $R$. collo-cygni and therefore the reason why one fungicide increases the mutation from the other fungicide group is not easily to justify. Several conclusions could be drawn from studies on Z. tritici, which is closely related to $R$. collocygni (McGrann et al., 2016; Stam et al., 2018). The population of $Z$. tritici is very heterogeneous in a single field or single trial (Stammler \& Semar, 2011) - this can lead to different DMI sensitivities and Cyp51 frequencies within one field or treatment. Moreover, earlier studies reported that different DMIs have a different impact on selecting for Cyp51 mutations (Cools, 2008; Heick et al., 2017a; Wieczorek et al., 2015). The most plausible explanation is provided by Stracke et al. (2018), who showed that $R$. collo-cygni isolates pretreated with prothioconazole were less sensitive to prothioconazole and additionally to benzovindiflupyr compared to the untreated control. Furthermore, the study by Rehfus et al. (2019) came to the result that isolates with low levels of DMI adaptation were connected 
to mutation in the SDH gene. This strong connection could lead to an increase of Cyp51 mutations after SDHI application. To elucidate why an SDHI application is increasing Cyp51 mutations, further work is needed. However, chlorothalonil in higher rates could hold Cyp51-I325T and $s d h C$ mutations at lower levels.

SDHIs and DMIs are key fungicides for disease management in barley and therefore the Fungicide Resistance Action Committee (FRAC) has been conducting monitoring programs in Europe for many years. In 2016, the first shifted or resistant isolates were found in Upper- and Lower Austria, especially in samples collected after SDHI application (Torriani S. and Bernhard-Frey R. 2019, personal communication). Our study is the first extensive monitoring of fungicide resistance within $R$. collo-cygni populations in Austria and the results are important for further management strategies in barley. Out of 58 samples in 2017, 2018 and 2019, only in five samples $R$. collo-cygni could not be detected. This shows that $R$. collo-cygni is present in all main barley growing areas, the Alpine-north climate region, the Pannonian climate region, the Illyrian and the Alpine-south climate region. In the Pannonian climate region, characterized through dry spring and summer periods, especially in the region east from Vienna, no Ramularia collo-cygni was detected in 2018 , but was found in 2019. This is contrary to the first Austrian findings of Huss et al. (2009) which refers to the lack of RLS in the dry eastern part of Austria. Hoheneder et al. (2021) showed that RLS level, sporulation rate and DNA content varied between years or different weather conditions. Especially long drought periods suppress RLS under field conditions. Our visible observations over several trials in different locations over the last years in Austria arrived at the same conclusions. $R$. collo-cygni with its large population and high mutation rate can therefore easily adapt to environmental conditions that may be exacerbated with climate change, which is increasing the range of the pathogen (Piotrowska et al., 2016; West et al., 2012).

The mutation development to DMI and SDHI fungicides in Western Europe is an ongoing process, especially the combined resistance towards SDHIs and DMIs (Rehfus et al., 2019). This is in line with findings in our study. In almost all cases Cyp51-I325T were detected together with $s d h C$ mutations. Cyp51-I325T mutation were found in higher frequencies compared to cum.-sdhC mutation - resulting in a lower performance of DMIs. Especially for Cyp51-I325T mutation, we found higher frequencies in the north compared to the south-east of Austria. This indicates that the resistance development has started in north-west and a northwest to south-east gradient exists. The moderate to high frequencies in Germany and no to low frequencies in Slovenia and Croatia as well as no Cyp51 mutation in Italy (FRAC 2020) support this assumption. Based on our study, it can be concluded that resistant strains of $R$. collo-cygni population did not increase over the last few years due to the well-established process of chlorothalonil application in Austria since the first detection of resistance. The frequency of Cyp51 and $s d h C$ mutations was significantly lower in 2019 compared to the previous two years. This decrease is associated with the general lower disease pressure in 2019 and the wide use of chlorothalonil. The lower frequency of mutations shows that DMIs and SDHIs still have performance in RLS control and mainly increase in yield is given through use of these fungicides. Nevertheless, an intensive and carefully considered management strategy is important to prolong the lifespan of DMIs and SDHIs.

The control on RLS heavily depended on the use of chlorothalonil; however, this multisite fungicide will not be available in future EU fungicide strategies due to recent regulations. Thus, QoIs, DMIs and SDHIs are brought more into focus, but in case of $R$. collo-cygni control all three groups are affected by site mutations, resulting in shifts in efficacy. The adding of sulphur, azoxystrobin and especially folpet in fungicide strategies with DMI plus SDHI resulted in a better RLS control compared to DMI plus SDHI alone. This shows that a fungicide strategy including more active ingredients from different fungicide groups are responsible for a better RLS control. Fungicide mixtures are also the key to slow down the emergence and selection of fungicide mutations and prolong effective life of fungicides (Van den Bosch et al., 2011). The loss of chlorothalonil will rapidly drive the spread and increase of resistance (Kildea et al., 2018). To counteract this, the authors refer to a moderate control where folpet is used and outlined the loss of around 10\% in yield through the replacement of chlorothalonil with folpet. The improved performance of folpet compared to sulphur were also raised by Stracke et al. (2018). The adding of azoxystrobin in the tank mix with prothioconazole plus benzovindiflupyr 
plus folpet showed no benefit in RLS control, but increased yield by $2 \%$. The G143 point mutation as described in Fountaine and Fraaije (2009) is responsible for the missing effectiveness of QoIs in RLS control while keeping sight of the fact that the positive physiological effect of azoxystrobin leads in a delay senescence and as a result increase in yield (Jorgensen \& Olesen, 2002). The disease severity in this trial was not very high, but folpet looks like a good replacement. Further investigations are necessary, especially to show if the selection process for DMI and SDHI mutations can be slow down and delay to protect DMIs and SDHIs in their efficacy.

Barley growers should adjust to the fact that RLS is present in the main Austrian barley growing areas and disease level will increase due to good adaptability to climate change. Based on the low to moderate Cyp51 and $s d h C$ frequencies and as well to protect other barley diseases, DMIs and SDHIs are essential to protect barley. To improve the lifetime of compounds with these modes of action, a focused application between GS 49 and 59 associated with the lowest recommended dose-rates of DMIs and SDHIs in combination with other active ingredients like folpet are essential, even if the combination of prothioconazole and benzovindiflupyr protected the yield under current situation. In the absence of new fungicides against RLS control, current fungicides have to be carefully used to prolong their activity as long as possible. From the agronomic point of view, this is a compromise to ensure yield and quality in barley.

Acknowledgements We thank F. Furtner for his help in data preparation and officials from Landwirtschaftskammer NOE and OOE for collecting leaves with RLS. We also thank the team of the Syngenta Disease Control Resistance Research for their support and the willingness to use their equipment.

Funding Open access funding provided by University of Natural Resources and Life Sciences Vienna (BOKU).

\section{Declarations}

Conflict of interests The authors declare no conflict of interest.

Ethical approval This paper does not contain studies on human or animal participants.

Informed consent The paper has not been submitted elsewhere for publication, in whole or in part. A.T. collected the field data. A.T., A.S. and B.-F.R. analysed laboratory data. A.T.,
F.J., T.S. and S.S. drafted the first manuscript and analysed the data. G.J. directed statistics for the AUDPC and yield efficacy response and population mutation survey data. All authors contributed to improve the manuscript, reviewed and approved the manuscript.

Open Access This article is licensed under a Creative Commons Attribution 4.0 International License, which permits use, sharing, adaptation, distribution and reproduction in any medium or format, as long as you give appropriate credit to the original author(s) and the source, provide a link to the Creative Commons licence, and indicate if changes were made. The images or other third party material in this article are included in the article's Creative Commons licence, unless indicated otherwise in a credit line to the material. If material is not included in the article's Creative Commons licence and your intended use is not permitted by statutory regulation or exceeds the permitted use, you will need to obtain permission directly from the copyright holder. To view a copy of this licence, visit http://creativecommons.org/licenses/by/4.0/.

\section{References}

AGES (Agentur für für Gesundheit und Ernährungssicherheit) (2020). Pflanzenschutzmittel-Register. https://psmregister. baes.gv.at/psmregister/faces/psm.jspx?_afrLoop=57456 3330521094\&_afrWindowMode $=0 \&$ locale $=$ de $\&$ refNr $=$ $11016499 \& \_a d f . c t r l-s t a t e=a v c f t a g p e \_14$. Accessed 2020.

Anonymous. (2012). Foliar and ear diseases on cereals. EPPO Bulletin, 42, 419-425.

Assinger, T., Torriani, S. F. F., Accardo, S., Fountaine, J., \& Steinkellner, S. (2021). Fungicide strategies and resistance of Ramularia collo-cygni to demethylation and succinate dehydrogenase inhibitors in Austrian winter barley (Hordeum vulgare). Journal of Plant Diseases and Protection, 128, 735-748.

Avenot, H. F., \& Michailides, T. J. (2010). Progress in understanding molecular mechanisms and evolution of resistance to succinate dehydrogenase inhibiting (SDHI) fungicides in phytopathogenic fungi. Crop Protection, 29, 643-651.

Brent, K. J., \& Hollomon, D. W. (2007). Fungicide Resistance in Crop Pathogens: How can it be managed? FRAC Monograph No. 1. Online publication. Croplife International, Brussels, Belgium. https://www.frac.info/docs/ default-source/publications/monographs/monograph-1. pdf. Accessed 2020.

Cook, N. M., Chng, S., Woodman, T. L., Warren, R., Oliver, R. P., \& Saunders, D. G. O. (2021). High frequency of fungicide resistance associated mutations in the wheat yellow rust pathogen Puccinia striiformis f. sp. tritici. Pest Management Science, 77, 3358-3371.

Cools, H. J. (2008). Are azole fungicides losing ground against Septoria wheat disease? Resistance mechanisms in Mycosphaerella graminicola. Pest Management Science, 64, 681-684.

Cromey, M. G., Butler, R. C., Mace, M. A., \& Cole, A. L. J. (2004). Effects of the fungicides azoxystrobin and 
tebuconazole on Didymella exitialis, leaf senescence and grain yield in wheat. Crop Protection, 23, 1019-1030.

Dooley, H., Shaw, M. W., Mehenni-Ciz, J., Spink, J., \& Kildea, S. (2016). Detection of Zymoseptoria tritici SDHIinsensitive field isolates carrying the SdhC-H152R and SdhD-R47W substitutions. Pest Management Science, 72, 2203-2207.

Fountaine, J. M., \& Fraaije, B. A. (2009). Development of QoI resistant alleles in populations of Ramularia collo-cygni. Aspects of Applied Biology, 92, 123-126.

Fraaije, B. A., Cools, H. J., Kim, S. H., Motteram, J., Clark, W. S., \& Lucas, J. A. (2007). A novel substitution I381V in the sterol 14 $\alpha$-demethylase (CYP51) of Mycosphaerella graminicola is differentially selected by azole fungicides. Molecular Plant Pathology, 8, 245-254.

FRAC (Fungicide Resistance Action Committee) (2019). Sterol Biosynthesis Inhibitor (SBI) Working Group. Published minutes of the 2019 annual meeting. www.frac. info. Accessed 2020

FRAC (Fungicide Resistance Action Committee) (2020). Sterol Biosynthesis Inhibitor (SBI) Working Group. Published minutes of the 2020 annual meeting. www.frac. info. Accessed 2020.

FRAC (Fungicide Resistance Action Committee) (2021). Succinate Dehydrogenase Inhibitor (SDHI) Working Group. Published minutes of the 2021 annual meeting. www.frac. info. Accessed 2021.

Gutiérrez-Alonso, O., Hawkins, N. J., \& Cools, H. J. (2017). Dose-dependent selection drives lineage replacement during the experimental evolution of SDHI fungicide resistance in Zymoseptoria tritici. Evolutionary Applications, $10,1055-1066$.

Harvey, I. C. (2002). Epidemiology and control of leaf and awn spot of barley caused by Ramularia collo-cygni. New Zealand Plant Protection, 55, 331-335.

Havis, N. D., Brown, J. K. M., Clemente, G., Frei, P., Jedryczka, M., Kaczmarek, J., Kaczmarek, M., Matusinsky, P., McGrann, G. R. D., Pereyra, S., Piotrowska, M., Sgheyr, H., Tellier, A., \& Hess, M. (2015). Ramularia collo-cygni - An emerging pathogen of barley crops. Phytopathology, 105, 895-904.

Havis, N., Gorniak, K., Stanisz-Migal, M., Creissen, H. E., \& Burnett, F. (2020). Controlling Ramularia leaf spot post chlorothalonil. Proceedings Crop Production in Northern Britain, 2020, 87-92.

Heick, T. M., Justesen, A. F., \& Jørgensen, L. N. (2017a). Antiresistance strategies for fungicides against wheat pathogen Zymoseptoria tritici with focus on DMI fungicides. Crop Protection, 99, 108-117.

Heick, T. M., Justesen, A. F., \& Jørgensen, L. N. (2017b). Resistance of wheat pathogen Zymoseptoria tritici to DMI and QoI fungicides in Nordic-Baltic region - a status. European Journal of Plant Pathology, 149, 669-682.

Hein, T. (2019). Barley breeding update. Europeanseed, 6(4), 6-8.

Hess, M., Weigand, S., \& Hausladen, H. (2009). Studying the epidemics of Ramularia collo-cygni in Germany and
Austria with different diagnostic tools; development of field diagnostics and implications for integrated disease control. Aspects of Applied Biology, 92, 9-16.

Hofer, K., Linkmeyer, A., Textor, K., Hückelhoven, R., \& Hess, M. (2015). MILDEW LOCUS 0 mutation does not affect resistance to grain infections with Fusarium spp. and Ramularia collo-cygni. Phytopathology, 105, 1214-1219.

Hoheneder, F., Hofer, K., Groth, J., Herz, M., Heß, M., \& Hückelhoven, R. (2021). Ramularia leaf spot disease of barley is highly host genotype-dependent and suppressed by continous drought stress in the field. Journal of Plant Diseases and Protection, 128, 749-767.

Huss, H., Eitzinger, J., \& Oberforster, M. (2009). Die Sprenkelkrankheit erstmals auch in Ostösterreich. Der Pflanzenarzt, 62(1-2), 22-24.

Jalli, M., Kaseva, J., Andersson, B., Ficke, A., Nilstrup-Jorgensen, L., Ronis, A., Kaukoranta, T., Orum, J.-E., \& Djurle, A. (2020). Yield increases due to fungicide control of leaf blotch diseases in wheat and barley as a basis for IPM decision-making in the Nordic-Baltic region. European Journal of Plant Pathology, 158, 315-333.

Jorgensen, L. N., \& Olesen, J. E. (2002). Fungicide treatments affect yield and moisture content of grain and straw in winter wheat. Crop Protection, 21, 1023-1032.

Kildea, S., Spink, J., \& Hennessy, M. (2018). An evaluation of the potential impact the loss of chlorothalonil may have on the productivity of winter wheat and spring and winter barley grown in Ireland. https://www.teagasc. $\mathrm{ie} /$ media/website/publications/2018/Potential-Impactsloss-of-chlorothalonil-may-have-on-cereal-production. pdf. Accessed 2020.

Kuznetsov, D., Cazenave, A. B., Rambach, O., Camblin, P., Nina, M., \& Leipner, J. (2017). Foliar application of benzovindiflupyr shows non-fungicidal effect in wheat plants. Pest Management Science, 74, 665-671.

Leadbeater, A. (2012). Resistance risk to QoI fungicides and anti-resistance strategies. In T. S. Thind (Ed.), Fungicide Resistance in Crop Protection: Risk and Management (pp. 141-154). Wallingford: U.K.: CAB International.

Leroux, P., \& Walker, A. S. (2011). Multiple mechanisms account for resistance to sterol 14 alpha-demethylation inhibitors in field isolates of Mycosphaerella graminicola. Pest Management Science, 67, 44-59.

Lynch, J. P., Glynn, E., Kildea, S., \& Spink, J. (2017). Yield and optimum fungicide dose rates for winter wheat (Triticum aestivum L.) varieties with contrasting ratings for resistance to Septoria tritici blotch. Field Crops Research, 204, 89-100.

Matsuzaki, Y., Kiguchi, S., Suemoto, H., \& Iwahashi, F. (2019). Antifungal activity of methyltetraprole against the existing QoI-resistant isolates of various plant pathogenic fungi. Pest Management Science, 76, 1743-1750.

McGrann, G. R. D., \& Havis, N. D. (2017). Ramularia leaf spot: A newly important threat to barley production. Outlooks on Pest Management, 28, 65-70.

McGrann, G. R. D., Andongabo, A., Sjökvist, E., Trivedi, U., Dussart, F., Kaczmarek, M., Mackenzie, A., Fountaine, 
J. M., Taylor, J. M. G., Paterson, L. J., Gorniak, K., Burnett, F., Kanyuka, K., Hammond-Kosack, K. E., Rudd, J. J., Blaxter, M., \& Havis, N. D. (2016). The genome of the emerging barley pathogen Ramularia collo-cygni. BMC Genomics, 17, 584-600.

McGrann, G. R. D., Miller, S., \& Havis, N. D. (2020). The Enhanced Magnaporthe Resistance 1 locus affects Ramularia leaf spot development in barley. European Journal of Plant Pathology, 156, 123-132.

Mulhare, J., Creissen, H. E., \& Kildea, S. (2021). Effectiveness of varietal resistance and risk prediction for the control of ramularia leaf spot of barley under Irish growing conditions. Crop Protection, 139. https://doi. org/10.1016/j.cropro.2020105317.

Parker, J. E., Warrilow, A. G. S., Cools, H. J., Martel, C. M., Nes, W. D., Fraaije, B. A., Lucas, J. A., Kelly, D. E., \& Kelly, S. L. (2011). Mechanism of binding of prothioconazole to Mycosphaerella graminicola CYP51 differs from that of other azole antifungals. Applied and Environmental Microbiology, 77, 1460-1465.

Piotrowska, M. J., Ennos, R. A., Fountaine, J. M., Burnett, F. J., Kaczmarek, M., \& Hoebe, P. N. (2016). Development and use of microsatellite markers to study diversity, reproduction and population genetic structure of the cereal pathogen Ramularia collo-cygni. Fungal Genetics and Biology, 87, 64-71.

Piotrowska, M. J., Fountaine, J. M., Ennos, R. A., Kaczmarek, M., \& Burnett, F. J. (2017a). Characterisation of Ramularia collo-cygni laboratory mutants resistant to succinate dehydrogenase inhibitors. Pest Management Science, 73, 1187-1196.

Piotrowska, M. J., Havis, N. D., Mackenzie, A., \& Burnett, F. J. (2017b). Fungicide sensitivity monitoring in cereals, forest and minor crop pathogens in the UK. In H. B. Deising, B. Fraaije, A. Mehl, E. C. Oerke, H. Sierotzki, \& G. Stammler (Eds.), Modern Fungicides and Antifungal Compounds Vol. VIII (pp. 135-140). Braunschweig: BCPC, DPG.

Rehfus, A., Matusinsky, P., Strobel, D., Bryson, R., \& Stammler, G. (2019). Mutations in target genes of succinate dehydrogenase inhibitors and demethylation inhibitors in Ramularia collo-cygni in Europe. Journal of Plant Diseases and Protection, 126, 447-459.

Sghyer, H., \& Hess, M. (2019). Culture conditions influence conidial production by the barley pathogen Ramularia collo-cygni. Journal of Plant Diseases and Protection, 126, 319-327.

Shaner, G., \& Finney, R. E. (1977). The effect of nitrogen fertilization on the expression of slow-mildewing resistance in knox wheat. Phytopathology, 67, 1051-1056.

Sierotzki, H., \& Scalliet, G. (2013). A review of current knowledge of resistance aspects for the next-generation succinate dehydrogenase inhibitor fungicides. Phytopathology, 103, 880-887.

Simoes, K., Hawlik, A., Rehfus, A., Gava, F., \& Stammler, G. (2018). First detection of a SDH variant with reduced
SDHI sensitivity in Phakopsora pachyrhizi. Journal of Plant Diseases and Protection, 125, 21-26.

Stam, R., Münsterkötter, M., Pophaly, S. D., Fokkens, L., Sghyer, H., Güldener, U., Hückelhoven, R., \& Hess, M. (2018). A new reference genome shows the one-speed genome structure of the barley pathogen Ramularia collocygni. Genome Biology and Evolution, 10, 3243-3249.

Stam, R., Sghyer, H., Tellier, A., Hess, M., \& Hückelhoven, R. (2019). The current epidemic of the barley pathogen Ramularia collo-cygni derives from a population expansion and shows global admixture. Phytopathology, 109, 2161-2168.

Stammler, G., \& Semar, M. (2011). Sensitivity of Mycosphaerella graminicola (anamorph: Septoria tritici) to DMI fungicides across Europe and impact on field performance. EPPO Bulletion, 41, 149-155.

Stetkiewicz, S., Burnett, F. J., Ennos, R. A., \& Topp, C. F. E. (2019). The impact of fungicide treatment and Integrated Pest Management on barley yields: Analysis of a long term field trials database. European Journal of Agronomy, 105, 111-118.

Stracke, A., von Tiedemann, A., \& Rodemann, B. (2018). Einfluss ausgewählter Fungizide auf die Bekämpfung von Ramularia collo-cygni in Gerste unter Berücksichtigung von Sensitivitätsanpassungen des Erregers. 61 Deutsche Pflanzenschutztagung. Julius-Kuehn-Archiv, 461, 425-426.

Sylvester, P. N., \& Kleczewski, N. M. (2018). Evaluation of foliar fungicide programs in mid-Atlantic winter wheat production systems. Crop Protection, 103, 103-110.

Torriani, S. F. F., Frey, R., Buitrago, C., Wullschleger, J., Waldner, M., Kuehn, R., Scalliet, G., \& Sierotzki, H. (2017). Succinate-Dehydrogenase Inhibitor (SDHI) Resistance Evolution in Plant Pathogens. In H. B. Deising, B. Fraaije, A. Mehl, E. C. Oerke, H. Sierotzki, \& G. Stammler (Eds.), Modern Fungicides and Antifungal Compounds Vol. VIII (pp. 89-94). Braunschweig: BCPC, DPG.

Van den Bosch, F., Paveley, N., Shaw, M., Hobbelen, P., \& Oliver, R. (2011). The dose rate debate: Does the risk of fungicide resistance increase or decrease with dose? Plant Pathology, 60, 597-606.

West, J. S., Townsend, J. A., \& Stevens, M. (2012). Comparative biology of different plant pathogens to estimate effects of climate change on crop diseases in Europe. European Journal of Plant Pathology, 133, 315-331.

Wieczorek, T. M., Berg, G., Semaskiene, R., Mehl, A., Sierotzki, H., Stammler, G., Justesen, A. F., \& Jorgensen, L. N. (2015). Impact of DMI and SDHI fungicides on disease control and CYP51 mutations in populations of Zymoseptoria tritici from Northern Europe. European Journal of Plant Pathology, 143, 861-871.

Wiik, L., \& Ewaldz, T. (2009). Impact of temperature and precipitation on yield and plant diseases of winter wheat in southern Sweden 1983-2007. Crop Protection, 28, 952-962.

Wullschleger, J., Sierotzki, H., \& Torriani, S. (2015). SEPTTRI q-PCR monitoring method Syngenta 2015. https:// 
www.frac.info/knowledge-database/monitoring-methods. Accessed 2020.

ZAMG (Zentralanstalt für Meteorologie und Geodynamik) (2020). HISTALP Berichte. https://www.zamg.ac.at/cms/ de/klima/news/histalp. Accessed 2020.

Zhang, Y., Zhou, Q., Tian, P., Li, Y., Duan, G., Li, D., Zhan, J., \& Chen, F. (2020). Induced expression of CYP51 associated with difenoconazole resistance in the pathogenic
Alternaria sect. on potato in China. Pest Management Science, 76, 1751-1760.

Zhou, T., \& Mehl, H. L. (2020). Rapid quantification of the G143A mutation conferring fungicide resistance in Virginia populations of Cercospora sojina using pyrosequencing. Crop Protection, 127. https://doi.org/10.1016/j. cropro.2019.104942. 